\title{
Seasonal physico-chemical characterization of water of sacred lake Nachiketa Tal, Garhwal Himalaya
}

\author{
Ramesh C. Sharma ${ }^{1} \cdot$ Vijayta Tiwari $^{1}$
}

Received: 30 October 2017 / Accepted: 11 September 2018 / Published online: 20 September 2018

(c) The Author(s) 2018

\begin{abstract}
The management of natural surface water resources needs the understanding of water quality. The present study on the physico-chemical parameters of water quality of sacred lake Nachiketa Tal of Garhwal Himalaya was undertaken. During the period from May 2015 to April 2016 at four sampling stations, seasonal variations in air temperature, water temperature, electrical conductivity, turbidity, salinity, TDS, dissolved oxygen, free $\mathrm{CO}_{2}$, hardness, alkalinity, nitrates, phosphates, chlorides, calcium and magnesium were recorded. The statistical correlation and cluster analysis between the various physico-chemical parameters of Nachiketa Tal were computed. The results of this study revealed that the concentration of the nutrients, turbidity, electrical conductivity, TDS increased with a decreasing trend of dissolved oxygen in all the sampling stations during the monsoon season. Thus, degradation in the water quality of the lake was resulted in the monsoon season.
\end{abstract}

Keywords Nachiketa Tal $\cdot$ Seasonal variations $\cdot$ Sacred lake $\cdot$ Garhwal Himalaya $\cdot$ India

\section{Introduction}

Lakes represent one of the most resourceful ecosystems on the Earth. In lakes, input and output of materials take place and therefore represent a continual chemical process like any other aquatic ecosystem. However, unlike rivers and ocean, limited mobility of material occurs in lakes. The sediments received by the lakes through inlets from catchment area erosion get progressively settled to the bottom of the lake. The water of the lake exits mostly through evaporation and outlet streams. In lentic ecosystem, there is a rapid interaction of sediment and water which increases the biological activities in the lakes (Chakrapani 2002). Lakes are dynamic lentic ecosystems which are significant inland water resources for meeting the increasing water demand. However, all these functions depend on the quality of water, which is based on a well-balanced environment in terms of its physical, chemical and biological variables (Yu et al. 2010). Melted water from the glaciers of Himalaya and seasonal snow covers plays an important role in the supply of water to the high-altitude

Vijayta Tiwari

vijayta29@gmail.com

1 Department of Environmental Sciences, H.N.B. Garhwal University (A Central University), Srinagar, Garhwal, Uttarakhand 246174, India lakes in Himalayan region (Xu et al. 2009). Chemistry of both the water and sediments of the lakes acts importantly in revealing the dynamics of Earth surface (Sheikh et al. 2014). Weathering of rocks from the catchment generates elemental ions and act as a natural pollutant source into the lakes (Das 2005). Mud, silt and human activities like washing and bathing mainly change the water chemistry. These water bodies are the major resource of water for consumption by humans and livestock, mainly for drinking and domestic purposes (Jeeji Bai and Lakshmi 1999). In addition to this, water quality of lakes is also impacted by dumping of religious offerings into the lakes (Dhote et al. 2001). Apart from this, lakes have significant economic values including supplying water for irrigation, power generation, providing food via fish and aquatic products and stabilizing the health and biodiversity of important life support ecosystem (ILEC 2003). Therefore, due to the quality of water from these water bodies, they are not always consumable or useful. So, there is a need for serious characterization of water physico-chemically before use. Generally, the lake water chemistry describes the seasonal variations in the behaviour of dissolved ions and catchment characteristics (Anshumali and Ramanathan 2007). In this paper, we have considered the Nachiketa Tal of Garhwal Himalaya for seasonal physico-chemical characterization of water. It acts as a natural water hole in the forests of Chaurangi khal for the wild animals and the villagers. It receives

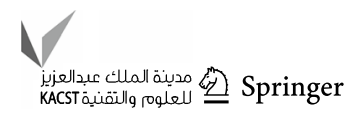


water from surface run-off. The major part of the lake catchment is rich in vegetation of Querecus, Abies, Rhododendron and Myrica. The water quality of Nachiketa Tal was assessed in terms of physico-chemical parameters during monsoon, winter, spring, autumn and summer seasons.

The Nachiketa Tal is one of the most important sacred lakes of Garhwal Himalaya. It is named after the son of sage Uddlak (Vajashravasa). He was well known for his curiosity to know the nature of human soul and the mysteries of death. Katha Upnishad has a reference that the sage Vajashravasa started offering to donate all his belongings in anticipation of gift from the God. However, the young son Nachiketa of Vajashravasa noticed that his father has donated only the barren, blind or lame cows. He was very much disturbed by the act of his father. Nachiketa asked his father, "I also belong to you, to which God will you offer me?" After asking several times, Vajashravasa answered in anger, "I will give you to Yam, the God of death". Therefore, Nachiketa left home in search of death. It was believed that Nachiketa after knowing the mysteries of death came for meditation at this lake, and the lake gets its name Nachiketa Tal. In Garhwal Himalaya, water of the lake is taken home as holy water. Every year on the day of Baishakhi, in the month of April, people of the nearby villages visit the lake in large number to perform various rituals. A temple of Annapoorna Devi and Nag Devta is also located at the bank of Nachiketa Tal.

\section{Materials and methods}

\section{Water sampling}

Four sampling stations $\left(S_{1}, S_{2}, S_{3}, S_{4}\right)$ have been identified for covering the entire ecosystem for seasonal physicochemical characterization of water of the Nachiketa Tal. The sampling station $S_{1}$ (disturbed site), the $S_{2}$ (highly disturbed site due to soil erosion) and the $S_{3}$ (least disturbed site) and the site $S_{4}$ (nearby temple) were identified. Five replicates of each sample from each sampling stations were taken for each parameter, and their statistical mean was computed. Water temperature and air temperature were measured in situ using the centigrade $\left(0-110^{\circ} \mathrm{C}\right)$ thermometer. However, the $\mathrm{pH}$ was measured by the Mac portable $\mathrm{pH}$ meter. Turbidity was determined using the Electronic India Digital Turbidity Meter (Model-331). Total dissolved solids (TDS) and electrical conductivity were recorded using the Toshcon Multiparameter Analyser. Dissolved oxygen, alkalinity, hardness, nitrates, phosphates, calcium and magnesium were estimated using the standard methods (Wetzel and Likens 1991; APHA 1998).

Nachiketa Tal is located between latitude $30^{\circ} 38.666^{\prime} \mathrm{N}$ and longitude $78^{\circ} 28.362^{\prime} \mathrm{E}$ at an altitude of $2453 \mathrm{~m}$ above m.s.l. in Garhwal Himalaya. The area of Nachiketa Tal is
0.49 ha. It is elliptical in shape, measuring about $132 \mathrm{~m}$ in length and $58 \mathrm{~m}$ width (Fig. 1). The lake remains occasionally covered with thick sheet of ice during the winter months of January and February. The lake depth varies from season to season and has no noticeable inlet as well as outlet. The depth of the Tal is maximum in rainy season. During the major part of the year, Nachiketa Tal remains shallow. The fast run-off from the forest deposited sediments in the lacustrine environment. Monthly sampling was undertaken during the morning time between 08:00 and 10:00 $\mathrm{h}$ during the period from May 2015 to April 2016.

\section{Results and discussion}

The data on seasonal variations in physico-chemical parameters at all the four sampling stations $\left(S_{1}, S_{2}, S_{3}, S_{4}\right)$ of Nachiketa Tal of Garhwal Himalaya have been recorded (Tables 1, 2, 3, 4) (Fig. 2). The air temperature was found to be maximum $\left(20.90 \pm 1.15{ }^{\circ} \mathrm{C}\right)$ in summer at $S_{4}$ and minimum $\left(7.27 \pm 2.93{ }^{\circ} \mathrm{C}\right)$ during winter at $S_{2}$ in the present study. The water temperature of the lake was found to be maximum $\left(17.73{ }^{\circ} \mathrm{C}\right)$ at $S_{1}$ in summer and minimum $\left(7.27{ }^{\circ} \mathrm{C}\right)$ at $S_{2}$ in winter season. Similar findings were reported by Iwona and Luari (2003) and Hassan et al. (2015) in their study areas. Electrical conductivity of the water signifies the presence of biogenic and abiogenic impurities in the water (Upadhyay et al. 2012). The significant seasonal variations in electrical conductivity were observed in the Nachiketa Tal. Seasonally, conductivity was found to be maximum $\left(67.05 \pm 1.63 \mu \mathrm{S} \mathrm{cm}^{-1}\right)$ at $S_{2}$ in monsoon and minimum $\left(31.0 \pm 2.0 \mu \mathrm{S} \mathrm{cm}^{-1}\right)$ at $S_{1}$ and $S_{4}$ in winter season during the present study. It was reported from the study on lakes of Jammu and Kashmir that the water conductivity decreases with an increase in its altitude (Zutshi et al. 1980). Since there is elevated temperature during the months of summer and monsoon seasons, the surface water evaporates resulting in an increase in the salt concentration in the waterbody (Kaushik and Saxena 1999). The high value of electrical conductivity in lakes also shows the pollution status (Kadam 1990). Nachiketa Tal has high conductivity during monsoon season, reflected the degraded water quality. $\mathrm{pH}$ indicates the nature of water quality as acidic or alkaline. It plays an important role in the biological process of all the aquatic organisms (Welch 1952). Maximum pH $(7.31 \pm 0.12)$ was recorded in the winter season and minimum $(6.76 \pm 0.06)$ in the monsoon season at $S_{4}$ in Nachiketa Tal. Higher $\mathrm{pH}$ in winter season was also reported by Virha et al. (2010) in the water of upper lake of Bhopal.

The concentration of seasonal variation in TDS was found maximum $\left(39.25 \pm 1.06 \mathrm{mg} \mathrm{l}^{-1}\right)$ in monsoon at site $S_{2}$ and minimum $\left(17.35 \pm 0.92 \mathrm{mg} \mathrm{l}^{-1}\right)$ at $S_{1}$ in autumn in Nachiketa Tal. The same trend of higher TDS in monsoon season was 
Fig. 1 Location of sampling stations $\left(S_{1}-S_{4}\right)$ in Nachiketa Tal, Garhwal Himalaya

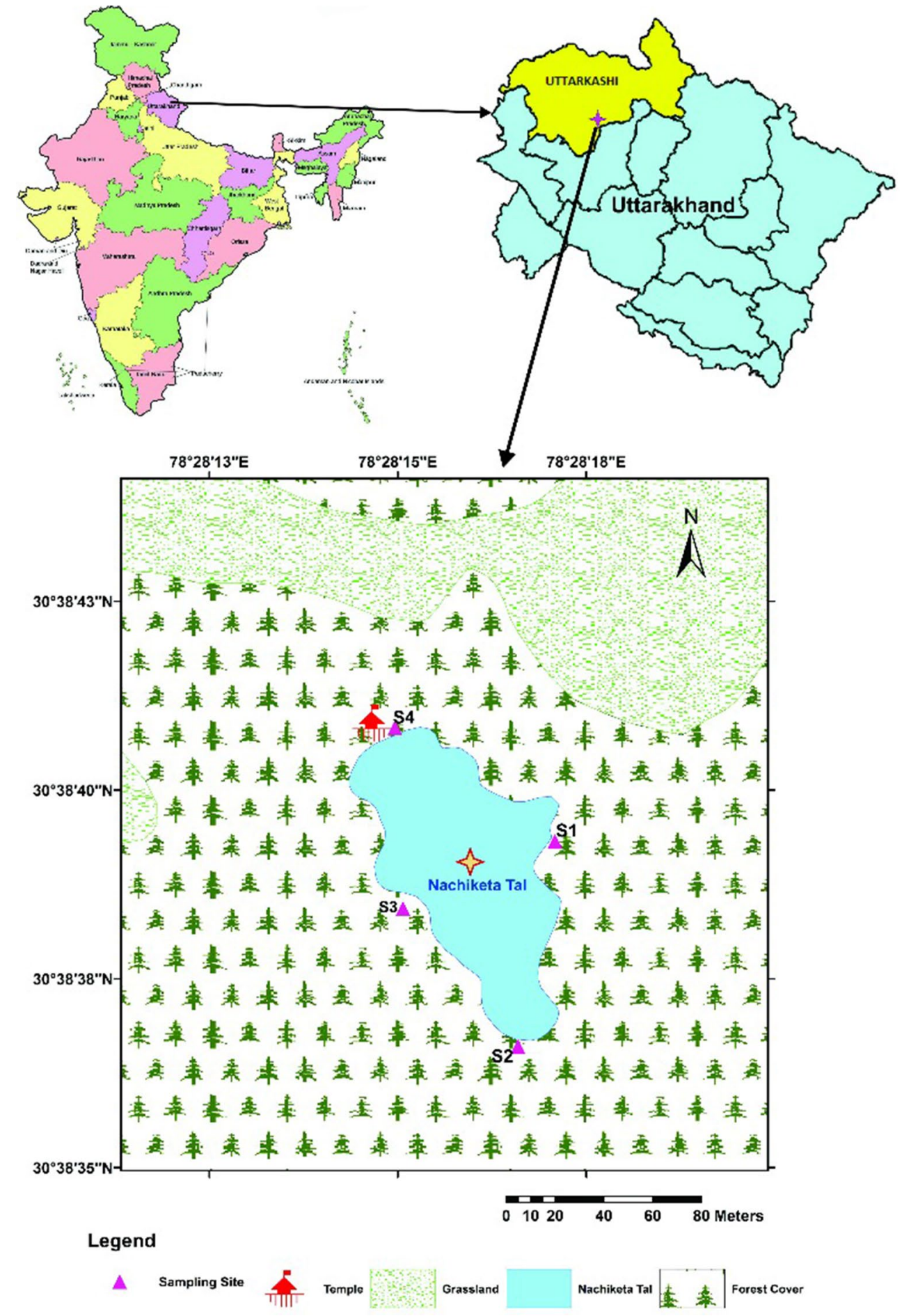

observed by Rawat et al. (1995) on Deaoria Tal and Surana et al. (2010) on Chimdi lake. Higher value of TDS in monsoon and lower values in post-monsoon seasons were also recorded by Rahaman et al. (2013). Similarly, the maximum turbidity $(8.1 \pm 0.42 \mathrm{NTU})$ was recorded at $S_{2}$ in monsoon and minimum $(3.08 \pm 0.41 \mathrm{NTU})$ during the winter season at $S_{1}$ in Nachiketa Tal. Turbidity in water body may be due to the suspended solid materials such as clay, silt, colloidal organic matter, plankton and other organisms (Dorner et al. 2007). According to Jain et al. (1999), highest sediment deposition during the rainy season turns the lake more turbid and also threatening the longevity of the lakes. Sharma and Rawat (2009) found the higher turbidity in the month of July and lower in the month of December in Asan wetland, Garhwal Himalaya. 
Table 1 Seasonal physicochemical characteristics of water at sampling station $S_{1}$ of Nachiketa Tal, Garhwal Himalaya
Table 2 Seasonal physicochemical characteristics of water at sampling station $S_{2}$ of Nachiketa Tal, Garhwal Himalaya

\begin{tabular}{|c|c|c|c|c|c|}
\hline Parameters & Summer & Monsoon & Autumn & Winter & Spring \\
\hline Air temperature $\left({ }^{\circ} \mathrm{C}\right)$ & $20.8 \pm 1.06$ & $20.5 \pm 0.71$ & $17.75 \pm 1.2$ & $11.2 \pm 2.57$ & $14.25 \pm 4.6$ \\
\hline Water temperature $\left({ }^{\circ} \mathrm{C}\right)$ & $17.73 \pm 1.37$ & $16.65 \pm 0.49$ & $15 \pm 0.71$ & $7.6 \pm 2.82$ & $11.3 \pm 5.09$ \\
\hline Electrical conductivity $\left(\mu \mathrm{S} \mathrm{cm}^{-1}\right)$ & $55.07 \pm 4.02$ & $62.2 \pm 0.85$ & $44.1 \pm 1.84$ & $31 \pm 2$ & $35 \pm 4.24$ \\
\hline Salinity (SAL) & $0.1 \pm 0$ & $0 \pm 0$ & $0.15 \pm 0.07$ & $0.2 \pm 0$ & $0.2 \pm 0$ \\
\hline $\mathrm{pH}$ & $6.79 \pm 0.06$ & $6.78 \pm 0.04$ & $6.91 \pm 0.01$ & $7.27 \pm 0.13$ & $7.16 \pm 0.34$ \\
\hline $\operatorname{TDS}\left(\mathrm{mg} \mathrm{l}^{-1}\right)$ & $30.47 \pm 8.64$ & $38.2 \pm 1.13$ & $17.35 \pm 0.92$ & $17.73 \pm 0.68$ & $17.4 \pm 1.13$ \\
\hline Turbidity (NTU) & $6.12 \pm 0.38$ & $7.75 \pm 0.49$ & $5.19 \pm 1.51$ & $3.08 \pm 0.41$ & $3.37 \pm 1.75$ \\
\hline $\mathrm{DO}\left(\mathrm{mg} \mathrm{l}^{-1}\right)$ & $7 \pm 0.2$ & $7.5 \pm 0.42$ & $8.25 \pm 0.35$ & $8.91 \pm 0.1$ & $8.7 \pm 0.71$ \\
\hline $\mathrm{BOD}\left(\mathrm{mg} \mathrm{l}^{-1}\right)$ & $1.67 \pm 0.12$ & $1.3 \pm 0.14$ & $1.08 \pm 0.18$ & $0.68 \pm 0.08$ & $0.95 \pm 0.07$ \\
\hline Free $\mathrm{CO}_{2}\left(\mathrm{mg} \mathrm{l}^{-1}\right)$ & $1.93 \pm 0.51$ & $2.83 \pm 0.05$ & $1.65 \pm 0.21$ & $1.05 \pm 0.13$ & $0.75 \pm 0.43$ \\
\hline Alkalinity $\left(\mathrm{mg} \mathrm{l}^{-1}\right)$ & $77.63 \pm 8.35$ & $76.25 \pm 2.47$ & $71.5 \pm 1.41$ & $53.33 \pm 11.55$ & $60 \pm 0$ \\
\hline Hardness (mg l ${ }^{-1}$ ) & $30.67 \pm 4.62$ & $23 \pm 4.24$ & $25 \pm 1.41$ & $26.07 \pm 0.12$ & $25 \pm 1.41$ \\
\hline Chlorides $\left(\mathrm{mg}^{-1}\right)$ & $4.58 \pm 0.96$ & $5.68 \pm 0$ & $3.4 \pm 0$ & $3.03 \pm 0.32$ & $3.66 \pm 0.42$ \\
\hline Nitrates $\left(\mathrm{mg} \mathrm{l}^{-1}\right)$ & $0.35 \pm 0.04$ & $0.44 \pm 0.02$ & $0.36 \pm 0.05$ & $0.3 \pm 0.02$ & $0.33 \pm 0.01$ \\
\hline Phosphates (mg 1 ${ }^{-1}$ ) & $0.07 \pm 0.01$ & $0.1 \pm 0$ & $0.07 \pm 0$ & $0.06 \pm 0.01$ & $0.06 \pm 0.01$ \\
\hline Sulphates $\left(\mathrm{mg}^{-1}\right)$ & $6.45 \pm 0.69$ & $8.63 \pm 0.61$ & $6.44 \pm 0.49$ & $5.88 \pm 0.52$ & $5.46 \pm 0.2$ \\
\hline Calcium (mg $\mathrm{l}^{-1)}$ & $7.21 \pm 2.12$ & $4.33 \pm 1.13$ & $5.21 \pm 0.57$ & $6.95 \pm 0.93$ & $5.21 \pm 0.57$ \\
\hline Magnesium (mg l$\left.{ }^{-1}\right)$ & $3.07 \pm 0.28$ & $2.96 \pm 0.34$ & $2.91 \pm 0$ & $2.12 \pm 0.58$ & $2.91 \pm 0$ \\
\hline
\end{tabular}

\begin{tabular}{lccccc}
\hline Parameters & Summer & Monsoon & Autumn & Winter & Spring \\
\hline Air temperature $\left({ }^{\circ} \mathrm{C}\right)$ & $20.27 \pm 1.08$ & $19.5 \pm 0.71$ & $17.15 \pm 1.2$ & $10.67 \pm 2.47$ & $13.45 \pm 4.31$ \\
Water temperature $\left({ }^{\circ} \mathrm{C}\right)$ & $17.17 \pm 1.26$ & $16.25 \pm 0.35$ & $14.6 \pm 0.57$ & $7.27 \pm 2.93$ & $10.75 \pm 4.88$ \\
Electrical conductivity $\left(\mu \mathrm{S} \mathrm{cm}^{-1}\right)$ & $60.47 \pm 1.62$ & $67.05 \pm 1.63$ & $47.9 \pm 2.69$ & $34.43 \pm 4.05$ & $37.1 \pm 4.67$ \\
Salinity (SAL) & $0.1 \pm 0$ & $0.05 \pm 0.07$ & $0.15 \pm 0.07$ & $0.2 \pm 0$ & $0.2 \pm 0$ \\
pH & $6.78 \pm 0.06$ & $6.76 \pm 0.09$ & $6.84 \pm 0.05$ & $7.16 \pm 0.2$ & $7.13 \pm 0.39$ \\
TDS $\left(\mathrm{mg} \mathrm{l}^{-1}\right)$ & $32.57 \pm 7.54$ & $39.25 \pm 1.06$ & $19.4 \pm 1.13$ & $18.07 \pm 0.74$ & $18.65 \pm 2.62$ \\
Turbidity $(\mathrm{NTU})$ & $6.77 \pm 0.66$ & $8.1 \pm 0.42$ & $5.3 \pm 1.53$ & $3.52 \pm 0.49$ & $4.59 \pm 0.87$ \\
DO $\left(\mathrm{mg} \mathrm{l}^{-1}\right)$ & $6.77 \pm 0.25$ & $7.15 \pm 0.49$ & $7.7 \pm 0.71$ & $8.53 \pm 0.06$ & $8.3 \pm 0.71$ \\
BOD $\left(\mathrm{mg} \mathrm{l}^{-1}\right)$ & $1.37 \pm 0.15$ & $1.2 \pm 0.28$ & $1 \pm 0.14$ & $0.57 \pm 0.21$ & $0.95 \pm 0.35$ \\
Free CO $\left(\mathrm{mg} \mathrm{l}^{-1}\right)$ & $1.93 \pm 0.51$ & $2.85 \pm 0.07$ & $1.8 \pm 0.28$ & $1.11 \pm 0.25$ & $0.78 \pm 0.42$ \\
Alkalinity $\left(\mathrm{mg} \mathrm{l}^{-1}\right)$ & $80.17 \pm 8.37$ & $78.2 \pm 2.83$ & $73.75 \pm 1.77$ & $54.83 \pm 9.39$ & $60.4 \pm 0.57$ \\
Hardness $\left(\mathrm{mg} \mathrm{l}^{-1}\right)$ & $28 \pm 0$ & $22 \pm 2.83$ & $25 \pm 1.41$ & $25.5 \pm 0.87$ & $25 \pm 1.41$ \\
Chlorides $\left(\mathrm{mg} \mathrm{l}^{-1}\right)$ & $4.58 \pm 0.96$ & $5.68 \pm 0$ & $3.4 \pm 0$ & $3.09 \pm 0.44$ & $3.66 \pm 0.42$ \\
Nitrates $\left(\mathrm{mg} \mathrm{l}^{-1}\right)$ & $0.35 \pm 0.01$ & $0.45 \pm 0.02$ & $0.36 \pm 0.03$ & $0.31 \pm 0.05$ & $0.35 \pm 0.04$ \\
Phosphates $\left(\mathrm{mg} \mathrm{l}^{-1}\right)$ & $0.07 \pm 0.01$ & $0.09 \pm 0.01$ & $0.07 \pm 0$ & $0.05 \pm 0.01$ & $0.05 \pm 0.01$ \\
Sulphates $\left(\mathrm{mg} \mathrm{l}^{-1}\right)$ & $6.9 \pm 0.43$ & $8.62 \pm 1.01$ & $7.12 \pm 1.42$ & $7.33 \pm 0.75$ & $6.4 \pm 0.05$ \\
Calcium $\left(\mathrm{mg} \mathrm{l}^{-1}\right)$ & $6.68 \pm 0.46$ & $4.01 \pm 1.13$ & $4.81 \pm 0$ & $6.95 \pm 0.93$ & $5.21 \pm 0.57$ \\
Magnesium $\left(\mathrm{mg} \mathrm{l}^{-1}\right)$ & $2.75 \pm 0.28$ & $2.91 \pm 0$ & $3.16 \pm 0.34$ & $1.98 \pm 0.49$ & $2.91 \pm 0$ \\
\hline
\end{tabular}

Dissolved oxygen in water is necessary for respiratory metabolism of most aquatic organisms and affects the solubility and availability of many nutrients and therefore determines the productivity of aquatic ecosystems (Wetzel 2001). DO was found to be maximum $\left(8.91 \pm 0.1 \mathrm{mg} \mathrm{l}^{-1}\right)$ at $S_{1}$ in winter season and minimum $\left(6.77 \pm 0.25 \mathrm{mg} \mathrm{l}^{-1}\right)$ at $S_{2}$ in summer season. The dissolved oxygen decreases during the summer season and steadily increases in autumn till maximum in winter following the well-known law of solubility of gases (Tian et al. 2012). Kaul and Handoo (1980) found the similar trend in Kashmir lakes. During the present study, BOD concentration was recorded higher values in summer $\left(1.67 \pm 0.12 \mathrm{mg} \mathrm{l}^{-1}\right)$ at $S_{1}$ and lower value in winter $\left(0.57 \pm 0.21 \mathrm{mg} \mathrm{l}^{-1}\right)$ at $S_{2}$ and $S_{3}$. Maximum BOD in summer and minimum in winter seasons were also reported by Liu et al. (2010). The free carbon dioxide in Nachiketa Tal was found to be maximum $\left(2.85 \pm 0.07 \mathrm{mg} \mathrm{l}^{-1}\right)$ in monsoon at $S_{2}$ and minimum 
Table 3 Seasonal physicochemical characteristics of water at sampling station $S_{3}$ of Nachiketa Tal, Garhwal Himalaya
Table 4 Seasonal physicochemical characteristics of water at sampling station $S_{4}$ of Nachiketa Tal, Garhwal Himalaya

\begin{tabular}{|c|c|c|c|c|c|}
\hline Parameters & Summer & Monsoon & Autumn & Winter & Spring \\
\hline Air temperature $\left({ }^{\circ} \mathrm{C}\right)$ & $20.57 \pm 0.81$ & $20.45 \pm 0.64$ & $17.9 \pm 1.56$ & $11.23 \pm 2.48$ & $14.2 \pm 4.67$ \\
\hline Water temperature $\left({ }^{\circ} \mathrm{C}\right)$ & $17.67 \pm 1.26$ & $16.75 \pm 0.35$ & $14.9 \pm 0.85$ & $7.37 \pm 2.84$ & $11.2 \pm 5.09$ \\
\hline Electrical conductivity $\left(\mu \mathrm{S} \mathrm{cm}^{-1}\right)$ & $54.83 \pm 4.66$ & $57.5 \pm 1.41$ & $40 \pm 0.71$ & $31.67 \pm 3.06$ & $34.5 \pm 3.54$ \\
\hline Salinity (SAL) & $0.1 \pm 0$ & $0.05 \pm 0.07$ & $0.15 \pm 0.07$ & $0.2 \pm 0$ & $0.2 \pm 0$ \\
\hline $\mathrm{pH}$ & $6.8 \pm 0.05$ & $6.78 \pm 0.08$ & $6.9 \pm 0.03$ & $7.22 \pm 0.23$ & $7.05 \pm 0.35$ \\
\hline $\operatorname{TDS}\left(\mathrm{mg} \mathrm{l}^{-1}\right)$ & $30.67 \pm 7.51$ & $37.6 \pm 0.57$ & $18.2 \pm 1.84$ & $17.5 \pm 0.87$ & $17.45 \pm 1.48$ \\
\hline Turbidity (NTU) & $6.18 \pm 0.32$ & $7.8 \pm 0.57$ & $5.2 \pm 1.52$ & $3.09 \pm 0.39$ & $3.4 \pm 1.82$ \\
\hline $\mathrm{DO}\left(\mathrm{mg} \mathrm{l}^{-1}\right)$ & $7.0 \pm 0.2$ & $7.45 \pm 0.35$ & $8.2 \pm 0.42$ & $8.83 \pm 0.06$ & $8.7 \pm 0.71$ \\
\hline $\mathrm{BOD}\left(\mathrm{mg} \mathrm{l}^{-1}\right)$ & $1.13 \pm 0.12$ & $1 \pm 0$ & $0.95 \pm 0.07$ & $0.57 \pm 0.21$ & $0.95 \pm 0.35$ \\
\hline Free $\mathrm{CO}_{2}\left(\mathrm{mg} \mathrm{l}^{-1}\right)$ & $1.93 \pm 0.51$ & $2.8 \pm 0.07$ & $1.65 \pm 0.21$ & $1.09 \pm 0.18$ & $0.75 \pm 0.43$ \\
\hline Alkalinity $\left(\mathrm{mg} \mathrm{l}^{-1}\right)$ & $77.4 \pm 7.97$ & $76.25 \pm 3.18$ & $70.25 \pm 0.35$ & $53.33 \pm 11.55$ & $60 \pm 0$ \\
\hline Hardness $\left(\mathrm{mg} \mathrm{l}^{-1}\right)$ & $29.33 \pm 2.31$ & $22.4 \pm 3.39$ & $25 \pm 1.41$ & $25.47 \pm 1.29$ & $25 \pm 1.41$ \\
\hline Chlorides $\left(\mathrm{mg} \mathrm{l}^{-1}\right)$ & $4.58 \pm 0.96$ & $5.68 \pm 0$ & $3.4 \pm 0$ & $3.03 \pm 0.32$ & $3.66 \pm 0.42$ \\
\hline Nitrates $\left(\mathrm{mg}^{-1}\right)$ & $0.34 \pm 0.01$ & $0.41 \pm 0.02$ & $0.34 \pm 0.05$ & $0.3 \pm 0.05$ & $0.37 \pm 0.03$ \\
\hline Phosphates $\left(\mathrm{mg} \mathrm{l}^{-1}\right)$ & $0.07 \pm 0.01$ & $0.08 \pm 0$ & $0.08 \pm 0.01$ & $0.05 \pm 0.01$ & $0.06 \pm 0.01$ \\
\hline Sulphates $\left(\mathrm{mg} \mathrm{l}^{-1}\right)$ & $6.73 \pm 0.8$ & $8.55 \pm 0.49$ & $6.35 \pm 0.35$ & $6.03 \pm 0.2$ & $5.79 \pm 0.09$ \\
\hline Calcium (mg l-1) & $6.95 \pm 0.93$ & $4.02 \pm 1.12$ & $5.61 \pm 1.13$ & $6.25 \pm 0.58$ & $5.37 \pm 0.34$ \\
\hline Magnesium $\left(\mathrm{mg} \mathrm{l}^{-1}\right)$ & $2.91 \pm 0$ & $3.01 \pm 0.14$ & $2.67 \pm 0.34$ & $2.4 \pm 0.06$ & $2.82 \pm 0.14$ \\
\hline
\end{tabular}

\begin{tabular}{lccccc}
\hline Parameters & Summer & Monsoon & Autumn & Winter & \multicolumn{1}{l}{ Spring } \\
\hline Air temperature $\left({ }^{\circ} \mathrm{C}\right)$ & $20.9 \pm 1.15$ & $20.5 \pm 0.71$ & $17.75 \pm 1.2$ & $11.13 \pm 2.69$ & $14 \pm 4.24$ \\
Water temperature $\left({ }^{\circ} \mathrm{C}\right)$ & $17.7 \pm 1.21$ & $16.75 \pm 0.35$ & $14.95 \pm 0.78$ & $7.6 \pm 2.82$ & $11.25 \pm 5.02$ \\
Electrical conductivity $\left(\mu \mathrm{S} \mathrm{cm}^{-1}\right)$ & $55.73 \pm 3.31$ & $63.05 \pm 0.21$ & $43.95 \pm 2.76$ & $31 \pm 2$ & $34.5 \pm 3.54$ \\
Salinity $(\mathrm{SAL})$ & $0.1 \pm 0$ & $0 \pm 0$ & $0.15 \pm 0.07$ & $0.2 \pm 0$ & $0.2 \pm 0$ \\
$\mathrm{pH}$ & $6.78 \pm 0.06$ & $6.76 \pm 0.06$ & $6.89 \pm 0.02$ & $7.31 \pm 0.12$ & $7.15 \pm 0.35$ \\
TDS $\left(\mathrm{mg} \mathrm{l}^{-1}\right)$ & $30.87 \pm 7.68$ & $38.25 \pm 1.06$ & $17.95 \pm 1.48$ & $17.8 \pm 0.75$ & $17.45 \pm 1.48$ \\
Turbidity $(\mathrm{NTU})$ & $6.12 \pm 0.38$ & $7.72 \pm 0.54$ & $5.22 \pm 1.52$ & $3.13 \pm 0.41$ & $3.38 \pm 1.8$ \\
DO $\left(\mathrm{mg} \mathrm{l}^{-1}\right)$ & $6.93 \pm 0.31$ & $7.5 \pm 0.42$ & $8.25 \pm 0.35$ & $8.8 \pm 0.2$ & $8.5 \pm 0.71$ \\
BOD $\left(\mathrm{mg} \mathrm{l}^{-1}\right)$ & $1.53 \pm 0.06$ & $1.5 \pm 0$ & $1.19 \pm 0.3$ & $0.77 \pm 0.12$ & $1.05 \pm 0.21$ \\
Free CO $\left(\mathrm{mg} \mathrm{l}^{-1}\right)$ & $1.93 \pm 0.51$ & $2.81 \pm 0.08$ & $1.65 \pm 0.21$ & $1.06 \pm 0.12$ & $0.75 \pm 0.43$ \\
Alkalinity $\left(\mathrm{mg} \mathrm{l}^{-1}\right)$ & $77.53 \pm 8.26$ & $76.4 \pm 2.26$ & $71 \pm 1.41$ & $53.33 \pm 11.55$ & $60.25 \pm 0.35$ \\
Hardness $\left(\mathrm{mg} \mathrm{l}^{-1}\right)$ & $30.83 \pm 4.48$ & $26 \pm 4.24$ & $25 \pm 1.41$ & $25.33 \pm 0.92$ & $25 \pm 1.41$ \\
Chlorides $\left(\mathrm{mg} \mathrm{l}^{-1}\right)$ & $4.58 \pm 0.96$ & $5.68 \pm 0$ & $3.4 \pm 0$ & $3.03 \pm 0.32$ & $3.66 \pm 0.42$ \\
Nitrates $\left(\mathrm{mg} \mathrm{l}^{-1}\right)$ & $0.35 \pm 0.02$ & $0.46 \pm 0.01$ & $0.4 \pm 0.04$ & $0.31 \pm 0.05$ & $0.34 \pm 0.02$ \\
Phosphates $\left(\mathrm{mg} \mathrm{l}^{-1}\right)$ & $0.07 \pm 0.01$ & $0.09 \pm 0$ & $0.08 \pm 0.01$ & $0.06 \pm 0.01$ & $0.06 \pm 0.01$ \\
Sulphates $\left(\mathrm{mg} \mathrm{l}^{-1}\right)$ & $6.57 \pm 0.73$ & $8.62 \pm 0.59$ & $8.25 \pm 2.05$ & $5.9 \pm 0.52$ & $5.47 \pm 0.21$ \\
Calcium $\left(\mathrm{mg} \mathrm{l}^{-1)}\right.$ & $7.48 \pm 1.85$ & $6.41 \pm 2.26$ & $5.61 \pm 1.13$ & $5.88 \pm 0.28$ & $5.21 \pm 0.57$ \\
Magnesium $\left(\mathrm{mg} \mathrm{l}^{-1}\right)$ & $2.96 \pm 0.07$ & $2.43 \pm 0.34$ & $2.67 \pm 0.34$ & $2.59 \pm 0.05$ & $2.91 \pm 0$ \\
\hline
\end{tabular}

$\left(0.75 \pm 0.43 \mathrm{mg} \mathrm{l}^{-1}\right)$ in spring at $S_{1}, S_{3}$ and $S_{4}$. Surana et al. (2010) also reported maximum free $\mathrm{CO}_{2}$ during monsoon seasons, because of the reduced photosynthesis during these months. Increased concentration of free $\mathrm{CO}_{2}$ in monsoon also indicates its influx through rainwater in the form of carbonic acid (Chakraborty et al. 1959).

The maximum alkalinity $\left(80.17 \pm 8.37 \mathrm{mg}^{-1}\right)$ was recorded in summer season at $S_{2}$ and minimum $\left(53.33 \pm 11.55 \mathrm{mg} \mathrm{l}^{-1}\right)$ in winter season at $S_{1}, S_{3}$ and $S_{4}$ in
Nachiketa Tal. Similar trend was reported by Sharma et al. (2011) in Lake Pichhola, Rajasthan.

Calcium and magnesium occur in all kinds of natural water. The concentration of calcium was found to be maximum $\left(7.48 \pm 1.85 \mathrm{mg}^{-1}\right)$ in summers at $S_{4}$ and minimum $\left(4.01 \pm 1.13 \mathrm{mg} \mathrm{l}^{-1}\right)$ in monsoon season at $S_{2}$. The concentration of magnesium was found to be minimum $\left(1.98 \pm 0.49 \mathrm{mg} \mathrm{l}^{-1}\right)$ at $S_{2}$ in winters and maximum 


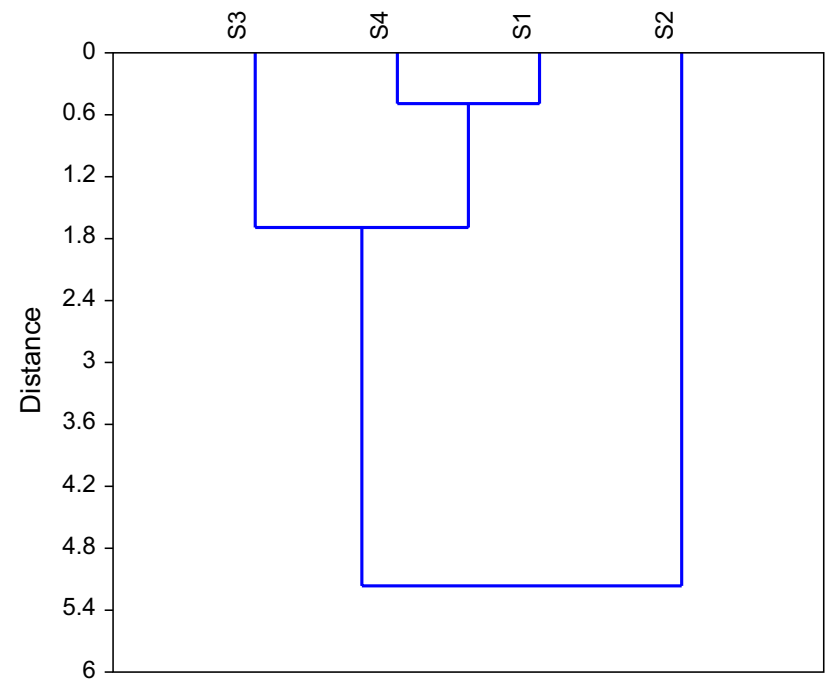

Fig. 2 Cluster analysis between sampling stations

$\left(3.16 \pm 0.34 \mathrm{mg}^{-1}\right)$ in autumn at $S_{2}$. Hardness is the property of water which prevents lather formation with soap. Hardness is mainly due to the presence of cations (calcium and magnesium) and anions mainly bicarbonates and carbonates. Seasonally, hardness was found to be maximum $\left(30.83 \pm 4.48 \mathrm{mg}^{-1}\right)$ in summer season at $S_{4}$ and minimum $\left(22 \pm 2.83 \mathrm{mg} \mathrm{l}^{-1}\right)$ in monsoon at $S_{2}$ in Nachiketa Tal. Maximum concentrations of hardness in summer and lower in monsoon were also reported by Hujare (2008). This may be due to the low water level and high rate of evaporation in the aquatic body. Chloride concentration in the water of Nachiketa Tal was maximum $\left(5.68 \pm 0 \mathrm{mg}^{-1}\right)$ in monsoon season at all the four stations and minimum $\left(3.03 \pm 0.32 \mathrm{mg}^{-1}\right)$ in winter season at $S_{4}$. Chemically, the most stable form of nitrogen is nitrate. In the present study, the values of nitrates were maximum $\left(0.046 \pm 0.01 \mathrm{mg} \mathrm{l}^{-1}\right)$ during monsoon season at $S_{4}$ and minimum $\left(0.030 \pm 0.02 \mathrm{mg} \mathrm{l}^{-1}\right)$ during winter at $S_{1}$ and $S_{2}$. Similar results were reported by Abir (2014) and Wondie et al. (2007) in their respective studies. Seasonally, phosphates concentration was high $\left(0.10 \pm 0 \mathrm{mg}^{-1}\right)$ during monsoon at $S_{1}$ and minimum $\left(0.05 \pm 0.01 \mathrm{mg} \mathrm{l}^{-1}\right)$ in winter at $S_{2}$ and $S_{3}$. The higher concentration of phosphates in monsoon season was also reported by Shukla et al. (2013) and Krishanmoorthi and Selvakumar (2012). Sulphates in the Nachiketa Tal were found to be maximum $\left(8.63 \pm 0.61 \mathrm{mg} \mathrm{l}^{-1}\right)$ in monsoon at $S_{1}$ and minimum $\left(5.46 \pm 0.2 \mathrm{mg} \mathrm{l}^{-1}\right)$ in spring at $S_{1}$. Similar trend of higher concentration of sulphates in monsoon season was reported by Abubakar (2012) in Nguru Lake of north-eastern Nigeria, and Latha and Mohan (2010) in Kommagatta Lake of Bangalore.

\section{Statistical treatment of data}

\section{Pearson's correlation coefficients}

Pearson's correlation coefficients were calculated for determining the relationship between the physico-chemical variables. Cluster analysis was applied to know the similarities between the sampling sites. The statistical treatment of data was done by using the PAST software. Pearson's correlation coefficients calculated between the physico-chemical attributes of Nachiketa Tal are presented in Table 5. Water temperature of the lake was directly influenced by the air temperature $(r=0.995, p<0.01)$. A positive correlation was found between the TDS and EC $(r=0.906, p<0.01)$. TDS was also positively co-related with the turbidity $(r=0.832$, $p<0.01)$. A negative relation $(r=-0.905, p<0.01)$ between the dissolved oxygen and water temperature. TDS is a direct measure of all the dissolved particles, both organic and inorganic in water. Higher TDS in monsoon in Nachiketa Tal is due to the surface runoff and sediment deposition in the lake from the catchment area. However, BOD was found to have positive correlation with water temperature ( $r=0.955$, $p<0.01)$. Sharma and Rawat (2009) also found a negative correlation between DO and water temperature in Asan wetland, Garhwal Himalaya. Photosynthetic activities of producers in the lakes also governed the $\mathrm{pH}$. Therefore, it reflects productive nature of the water body (Upadhyay et al. 2012). A negative correlation $(r=-0.961, p<0.01)$ was found between the $\mathrm{pH}$ and water temperature in Nachiketa Tal. Nitrates in the water of the lake were found positively correlated with the turbidity $(r=0.729, p<0.01)$.

\section{Cluster analysis}

Cluster analysis was applied to know the similarities between the sampling stations. In the cluster analysis, the distance ranged from 0 to 6.00 . It revealed the similarity between $S_{1}$ and $S_{4}$ (Fig. 2).

\section{Conclusion}

The present study on seasonal physico-chemical characterization of water of Nachiketa Tal revealed that the water quality of the Nachiketa Tal was degraded during monsoon season. In monsoon season, the lake receives sediments, litter and other organic pollutants, consequently increasing the turbidity, TDS, EC and nutrients like nitrates and phosphates in the lake. Water quality of the Nachiketa Tal was better during winter season. The highest dissolved oxygen was found in winter season in Nachiketa Tal during its low water temperature. Cluster analysis between the sampling stations of Nachiketa Tal revealed that the 


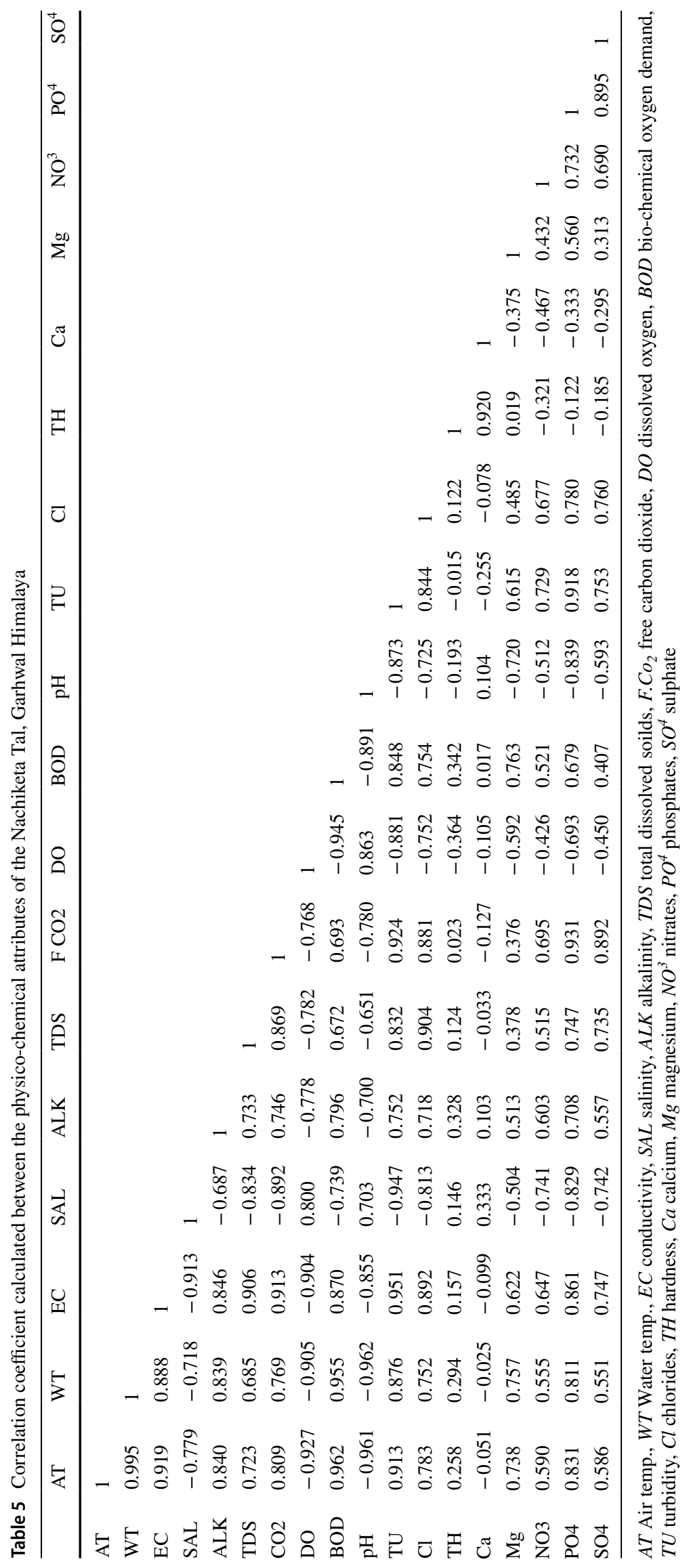


sampling stations $S_{1}$ and $S_{4}$ have close similarity, as both receive the anthropogenic pressures. Therefore, there is an urgent need to reduce the natural and anthropogenic pressures on the water of Nachiketa Tal during monsoon season for providing goods and services including drinking water to the people.

Acknowledgements One of the authors (Vijayta Tiwari) is thankful to the University Grant Commission, New Delhi, and H.N.B. Garhwal University (A Central University), Srinagar-Garhwal, Uttarakhand, for providing Central University fellowship for undertaking the present work.

Open Access This article is distributed under the terms of the Creative Commons Attribution 4.0 International License (http://creativeco mmons.org/licenses/by/4.0/), which permits unrestricted use, distribution, and reproduction in any medium, provided you give appropriate credit to the original author(s) and the source, provide a link to the Creative Commons license, and indicate if changes were made.

\section{References}

Abir S (2014) Seasonal variations in physico-chemical characteristics of Rudrasagar Wetland: a Ramsar site, Tripura, north East, India. Res J Chem Sci 4(1):31-40

Abubakar MM (2012) Effects of physico-chemical factors on seasonal dynamics of the phytoplankton in Nguru lake, Northeastern Nigeria. J Nat Sci Res 2(8):74-81

Anshumali, Ramanathan AL (2007) Seasonal variation in the major ion chemistry of Pandoh Lake, Mandi District, Himachal Pradesh, India. Appl Geochem 22:1736-1747

APHA (1998) Standard methods for the examination of water and wastewater. American Public Health Association, Washington, pp 1-1368

Chakraborty R, Ray DP, Singh SB (1959) A quantitative study of the plankton and physicochemical conditions of the River Jamuna at Allahabad in 1954-55. Indian J Fish 6(1):186-203

Chakrapani GJ (2002) Water and sediment geochemistry of major Kumaun Himalayan lakes, India. Environ Geol 43:99-107

Das BK (2005) Environmental pollution impact on water and sediments of Kumaun lakes, Lesser Himalaya, India: a comparative study. Environ Geol 49:230-239

Dhote S, Varghese B, Mishra SM (2001) Impact of idolimmersion on water quality of twin lakes of Bhopal. Indian J Environ Prot 21:998-1005

Dorner SM, Anderson WB, Gaulin T, Candon HL, Slawson RM, Payment P, Huck PM (2007) Pathogen and indicator variability in a heavily impacted watershed. J Water Health 5(2):241-257

Hassan Z, Shah JA, Kanth TA, Pandit AK (2015) Influence of land use/land cover on the water chemistry of Wular Lake in Kashmir Himalaya (India). Ecol Process 4:9

Hujare MS (2008) Seasonal Variation of Physico chemical parameters in perennial tank of Talsande, Maharashtra. Ecotoxicol Environ Monit 18(3):233-242

ILEC (2003) World lake vision: a call to action. ILEC. Information Sheet on Ramsar Wetlands, Kusatsu

Iwona J, Luari A (2003) Potential effects of factors on the abundance of autotrophic phytoplankton in four boreal lakes. J Plankton Res 25(8):873-883
Jain A, Rai SC, Pal J, Sharma E (1999) Hydrology and nutrient dynamics of a sacred lake in Sikkim Himalaya. Hydrobiologia 416:13-22

Jeeji Bai N, Lakshmi D (1999) On the Phytoplankton flora of a few temple tanks in Madras and their unique phycobicoenoses. In: Durgaprasad MK, Sankara Pitchaiah P (eds) Inland water resources-India. Discovery Publishing House, New Delhi, pp 185-199

Kadam SD (1990) Environmental study of lake Rankala, Jaynati Nala and Lake Kotitirth from Kolhapur city. Environ Ecol 8(1):95-97

Kaul V, Handoo JK (1980) Physicochemical characteristics of Nilang-a high altitude forest lake of Kashmir and its comparison with valley lakes. Proc Indian Natl Sci Acad B 46(4):528-541

Kaushik S, Saxena MN (1999) Physico-chemical limnology of certain water bodies of Central India. In: Daya VK (ed) Freshwater ecosystems of India. Publishing House, Delhi, pp 1-58

Krishanmoorthi A, Selvakumar S (2012) Seasonal fluctuation of zooplankton community in relation to certain physico-chemical parameters of Veeranam lake in Cuddalore District, Tamil Nadu. Int J Res Environ Sci Technol 2(2):22-26

Latha N, Mohan R (2010) Studies on enviro-ecological status of Kommagatta lake of Bangalore, Karnataka. Indian Hydrobiol 12(2):126-129

Liu C, Liu L, Shen H (2010) Seasonal variations of phytoplankton community structure in relation tophysico-chemical factors in Lake Baiyangdian, China. Procedia Environ Sci 2:1622-1631

Rahaman SMB, Sarder L, Rahaman MS, Ghosh AK, Biswas SK, Siraj SS, Haq KA, Hasanuzzaman AFM, Islam SS (2013) Nutrient dynamics in the Sundarbans mangroves estuarine system of Bangladesh under different weather and tidal cycles. Ecol Process 2:29

Rawat MS, Juyal CP, Sharma RC (1995) Morphometry and physicochemical profile of high altitude lake Deoria Tal of Garhwal Himalaya. J Freshw Biol 7(1):1-6

Sharma RC, Rawat JS (2009) Monitoring of aqyatic macroinvertebrates as bioindicator for assessing the health of wetlands: a case study in the Central Himalayas, India. Ecol Ind 9:118-128

Sharma R, Sharma V, Sharma MS, Verma BK, Modi R, Gaur KS (2011) Studies on limnological characteristic, plankton diversity and fishes (species) in Lake Pichhola, Udaipur, Rajasthan (India). Univers J Environ Res Technol 1(3):274-285

Sheikh JA, Jeelani G, Gavali RS, Shah RA (2014) Weathering and anthropogenic influences on the water and sediment chemistry of Wular Lake, Kashmir Himalaya. Environ Earth Sci 71:2837-2846

Shukla P, Preeti, Singh A (2013) A seasonal variations of plankton population of Maheshara Lake in Gorakhpur, India. World J Zool 8(1):09-16

Surana R, Subba BR, Limbu KP (2010) Physico-chemical studies on Chimdi lake of Sunsari District during its restoration stage. Our Nat 8:258-269

Tian C, Lu X, Pei H, Hu W, Xie J (2012) Seasonal dynamics of phytoplankton and its relationship with the environmental factors in Dongping lake, China. Environ Monit Assess 185:2627-2645

Upadhyay R, Pandey AK, Upadhyay SK, Bassin JK, Misra SM (2012) Limnochemistry and nutrient dynamics in Upper Lake, Bhopal, India. Environ Monit Assess 184:7065-7077

Virha R, Biswas AK, Kakaria VK, Qureshi TA, Borana K, Malik N (2010) Seasonal variation in physicochemical parameters and heavy metals in water of Upper Lake of Bhopal. Bull Environ Contam Toxicol 86:168-174

Welch PS (1952) Limnology, 2nd edn. Mc Graw-Hill Book Company Inc, New York

Wetzel RG (2001) Limnology: lake and river ecosystems, 3rd edn. Academic Press, California 
Wetzel RG, Likens GE (1991) Limnological analyses, 2nd edn. Springer, New York, pp 1-175

Wondie A, Mengistu S, Vijverberg J, Dejen E (2007) Seasonal variation in primary production of a large high altitude tropical lake (Lake Tana, Ethiopia): effects of nutrient availability and water transparency. Aquat Ecol 41:195-207

Xu J, Grumbine E, Shrestha A, Eriksson M, Yang X, Wang Y, Wilkes A (2009) The melting Himalayas: cascading effects of climate change on water, biodiversity, and livelihoods. Conserv Biol 235:20-30

Yu F, Fang G, Ru X (2010) Eutrophication, health risk assessment and spatial analysis of water quality in Gucheng Lake, China. Environ Earth Sci 59(8):1741-1748
Zutshi DP, Subla BA, Khan MA, Wanganeo A (1980) Comparative limnology of nine lakes of Jammu and Kashmir Himalayas. Hydrobiology 72:101-112

Publisher's Note Springer Nature remains neutral with regard to jurisdictional claims in published maps and institutional affiliations. 